\title{
Meningkatkan kemandirian dan hasil belajar peserta didik menggunakan Kvisoft Flipbook Maker berbasis Android
}

\author{
Siti Akhlaqul Karimah, Madziatul Churiyah* \\ Universitas Negeri Malang, Jl. Semarang No. 5 Malang, Jawa Timur, Indonesia \\ *Penulis korespondensi, Surel: madziatul.churiyah.fe@um.ac.id
}

Paper received: 7-6-2021; revised: 21-6-2021; accepted: 28-6-2021

\begin{abstract}
Abstrak
Pendidikan merupakan aset yang paling penting bagi sumber daya manusia. Pendidikan juga akan terus berkembang dari waktu ke waktu sesuai dengan perkembangan zaman. Hal ini bertujuan untuk meningkatkan keefektifan dalam suatu pembelajaran. Dengan hal ini, perlu dikembangkannya bahan ajar yang sesuai dengan kebutuhan serta memanfaatkan teknologi yang berkembang saat ini. Oleh karena itu, penelitian ini bertujuan meningkatkan kemandirian dan hasil belajar peserta didik. Penelitian dan pengembangan menggunakan metode Research and Development Borg and Gall yang telah dimodifikasi. Teknik analisis data menggunakan Teknik kuantitatif dan kualitatif. Hasil penelitian dan pengembangan ini adalah pengembangan E-Modul Berbasis Android Menggunakan Aplikasi Kvisoft Flipbook Maker Pada Mata Pelajaran Humas yang telah dinyatakan sangat valid dan layak digunakan dalam pembelajaran humas oleh ahli materi dan ahli media dan 6 peserta didik uji coba kelompok kecil serta terbukti secara signifikan pada uji coba kelompok besar. Sehingga dapat disimpulkan bahwa E-Modul Humas layak digunakan untuk meningkatkan kemandirian dan hasil belajar peserta didik pada mata pelajaran Humas.
\end{abstract}

Kata kunci: penelitian dan pengembangan; e-modul; kvisoft flipbook maker; android; kemandirian; hasil belajar.

\section{Pendahuluan}

Berkembangnya virus Covid-19 di awal tahun 2020 berdampak pada Pendidikan di Indonesia (Sari, Tusyantari and Suswandari, 2021). Dampak virus Covid-19 ini terhadap Pendidikan sangat besar, apalagi dirasakan oleh berbagai pihak seperti guru, peserta didik dan para orang tua. Akibat dari pandemi Covid-19 ini dari Universitas sampai sekolah dasar diliburkan (Fredy, Prihandoko and Anggawirya, 2020). Oleh karena itu, Pendidikan di Indonesia melakukan Pembelajaran Daring dengan menggunakan media pembelajaran dan beberapa platform online yang popular dan sudah dipersiapkan oleh para guru (Mishra, Gupta and Shree, 2020). Kegiatan pembelajaran selama pandemi Covid-19 diperlukan media pembelajaran yang memanfaatkan teknologi yang berkembang saat ini supaya guru dan peserta didik dapat melakukan pembelajaran secara bersamaan meskipun ditempat yang berbeda (Badrudin, Ginanjar and Wartono, 2020).

Dengan memanfaatkan teknologi digital, peserta didik banyak mendapatkan kemudahan-kemudahan (Lestari, 2018). Salah satunya menggunakan modul yang bisa diakses melalui android.

Salah satu bentuk pembelajaran untuk memudahkan peserta didik yaitu dengan menggunakan E-Modul yang bisa digunakan di smartphone android. Sehingga dapat memudahkan guru untuk menyampaikan pembelajaran jarak jauh (Ramdhani and Muhammadiyah, 2015). E-Modul yang dikembangkan dalam penelitian ini yaitu E-Modul berbasis android menggunakan aplikasi kvisoft flipbook maker.

This work is licensed under a Creative Commons Attribution-ShareAlike 4.0 International License. 
Beberapa penelitian sebelumnya dan yang sudah mengembangkan E-Modul berbasis android menggunakan aplikasi Kvisoft Flipbook Maker yaitu sebagai berikut (Damarsasi, D. G., \& Saptorini, 2018), (Fonda and Sumargiyani, 2018), (Putri, Uchtiawati and Fauziyah, 2020), (Linda et al., 2018), (Wibowo and Pratiwi, 2018), (Divayana et al., 2019) berdasarkan penelitian-penelitian tersebut dapat disimpulkan bahwa E-Modul berbasis android menggunakan aplikasi Kvisoft Flipbook Maker dapat meningkatkan hasil belajar dan kemandirian peserta didik.

Akan tetapi, berdasarkan hasil wawancara dengan guru mata pelajaran Otomatisasi Tata Kelola Humas dan Keprotokolan kelas XI OTKP di SMK Terpadu Al-Ishlahiyah Singosari. Didapatkan informasi bahwa di SMK Terpadu Al-Ishlahiyah melakukan kegiatan luring dan daring, dimana setiap kelas hanya masuk dengan jadwal yang berbeda yaitu 2 hari per kelas seperti kelas XI OTKP hanya masuk pada hari rabu dan kamis. Masih adanya kegiatan secara daring dan pembelajarannya dipersingkat membuat waktu penyampaian materi oleh guru yang diberikan kepada peserta didik jauh lebih dipersingkat menyebabkan peserta didik harus belajar sendiri di rumah. Dari masalah tersebut, peneliti mengembangkan E-Modul berbasis android menggunakan aplikasi Kvisoft Flipbook Maker yang bisa diinstal di android peserta didik dan bisa digunakan offline maupun online pada mata pelajaran Otomatisasi Tata Kelola Humas dan Keprotokolan. Isi dari E-Modul sendiri ada latihan soal, video pembelajaran, materi serta games sehingga peserta didik dapat belajar secara mandiri dan mengerjakan latihan soal di E-Modul tersebut.

\section{Metode}

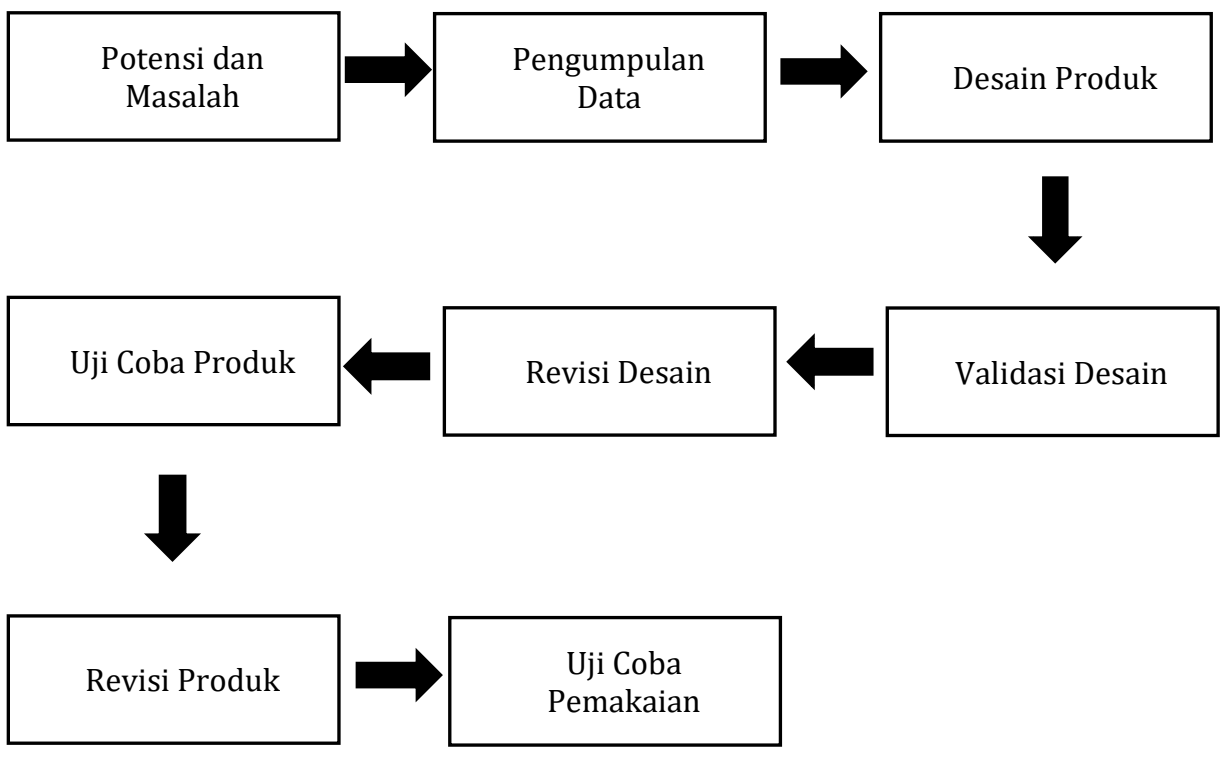

Gambar 1. Langkah-langkah penelitian

Penelitian ini menggunakan model Research and Development Brog and Gall menurut Sugiyono setelah dimodifikasi menjadi delapan langkah untuk mempersingkat waktu dan keadaan lapangan (Sugiyono, 2016), (Dwiantoro and Kusumandari, 2016), . Selain itu peneliti juga merasa bahwa penelitian ini yaitu untuk menghasilkan produk, mengetahui kelayakan 
produk dan mengetahui perbedaan hasil belajar dan kemandirian peserta didik yang menggunakan E-Modul dan yang tidak menggunakan E-Modul.

Langkah awal yaitu peneliti melakukan observasi potensi dan masalah yang terjadi di SMK. Langkah kedua, peneliti mengumpulkan informasi tentang perencanaan produk. Langkah ketiga, peneliti melakukan desain produk E-Modul berdasarkan rancangan yang telah ditentukan. Langkah keempat, produk E-Modul yang telah dikembangkan peneliti diuji kelayakan oleh validator ahli media. Langkah kelima, setelah diuji oleh validator kemudian produk E-Modul dilakukan revisi berdasarkan saran dan kritik dari validator ahli media untuk menyempurnakan produk. Langkah keenam, produk yang telah direvisi kemudian diujicobakan pada 6 siswa kelas XI OTKP 2 yang menjadi kelas eksperimen pada penelitian ini dan bisa diakses melalui link http://bit.ly/E-ModulHumas. Langkah ketujuh, setelah diuji cobakan pada 6 siswa kemudian produk akan direvisi lagi berdasarkan saran dan kritik dari peserta didik. Langkah kedelapan, setelah direvisi kemudian produk akan diujicobakan pada kelompok besar yang melibatkan 25 siswa kelas XI OTKP 1 selaku kelas kontrol dan 25 siswa kelas XI OTKP 2 selaku kelas eksperimen.

Data yang dihasilkan pada penelitian ini menggunakan data kualitatif dan kuantitatif. Dimana data kuantitatif meliputi ahli media, ahli materi, kelompok kecil yang berjumlah 6 siswa, hasil belajar dan kemandirian belajar, sedangkan kualitatif meliputi ahli media, ahli materi dan kelompok kecil yang berjumlah 6 siswa. Data hasil validasi ahli materi, ahli media, uji coba kelompok kecil, hasil belajar dan kemandirian belajar dianalisis menggunakan metode deskriptif persentase untuk menunjukkan tingkat kelayakan media pembelajaran.

\section{Hasil dan Pembahasan}

Produk yang dihasilkan dalam penelitian dan pengembangan ini adalah E-Modul berbasis android menggunakan aplikasi Kvisoft Flipbook Maker pada mata pelajaran Otomatisasi Tata Kelola Humas dan Keprotokolan. E-Modul berbasis android menggunakan aplikasi Kvisoft Flipbook Maker terdiri terdiri dari menu yang dijelaskan melalui Gambar 2 berikut ini:

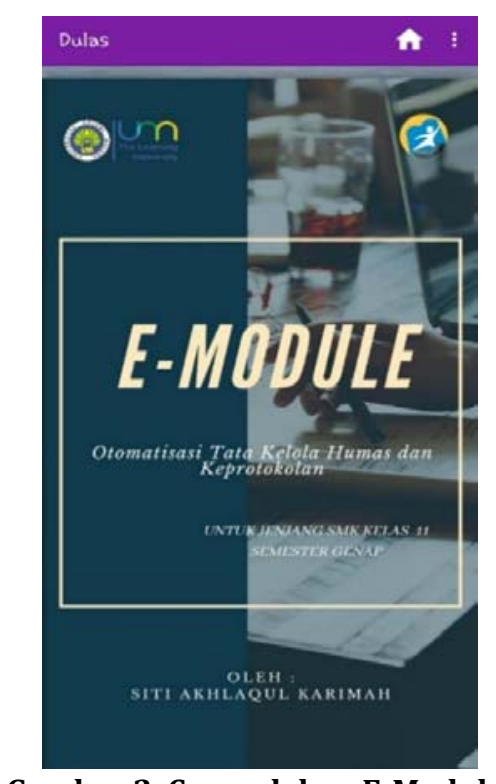

Gambar 2. Cover dalam E-Modul 
Setelah di halaman cover pengguna akan menuju ke halaman selanjutnya yaitu halaman kata pengantar, daftar isi dan pendahuluan seperti pada gambar 3.
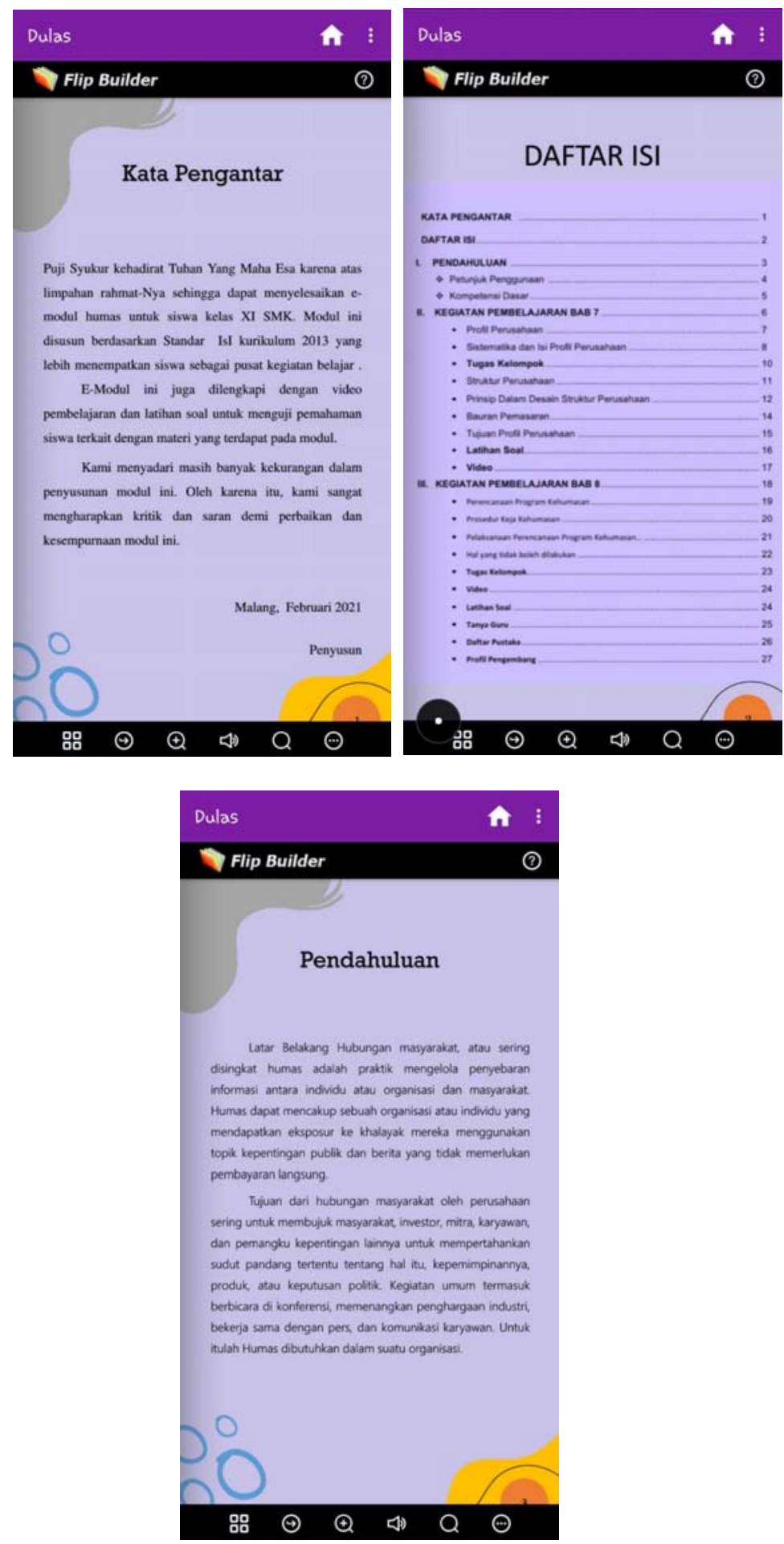

Gambar 3. Kata pengantar, daftar isi dan pendahuluan dalam E-Modul

Selanjutnya pengguna akan menjumpai halaman petunjuk penggunaan seperti pada gambar 4. 


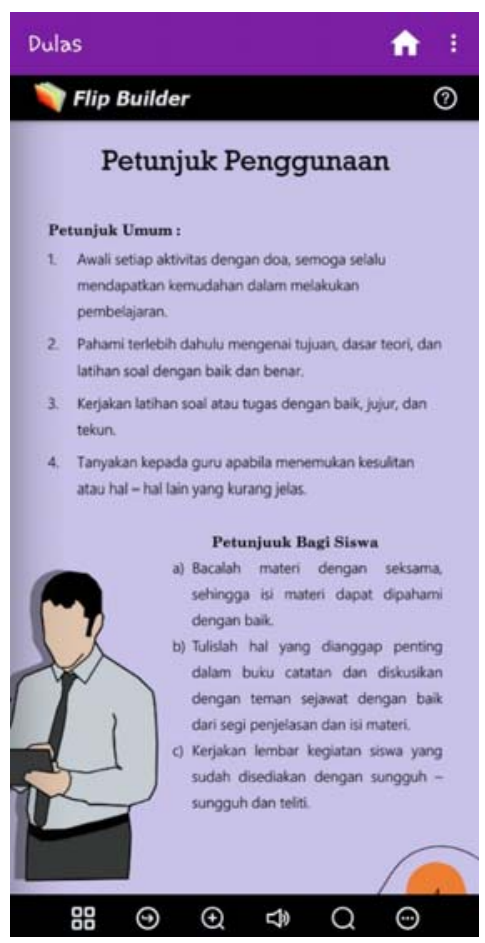

Gambar 4. Petunjuk penggunaan dalam E-Modul

Hasil validasi E-Modul Humas oleh ahli media, ahli materi dan uji coba kelompok kecil yang disajikan pada tabel 1 berikut ini:

Tabel 1. Data hasil validasi keseluruhan

\begin{tabular}{llll}
\hline No & Validasi & Persentase & Kriteria Validitas \\
\hline 1. & Ahli Media & $93 \%$ & Sangat Valid \\
2. & Ahli Materi & $91 \%$ & Sangat Valid \\
3. & Uji Coba Kelompok Kecil & $91 \%$ & Sangat Valid \\
Rata-rata & $92 \%$ & Sangat Valid \\
\hline
\end{tabular}

Tabel used by permission (CKarimah, Siti Akhlaqul, 2021. Data hasil validasi keseluruhan

Berdasarkan Tabel 1 diatas, diketahui rata-rata hasil validasi keseluruhan yaitu 92\%, sehingga dapat disimpulkan bahwa E-Modul Humas yang dikembangkan peneliti dapat dinyatakan "Sangat Valid" dan layak untuk digunakan dalam pembelajaran Humas di SMK Terpadu Al-Ishlahiyah Singosari. Sejalan dengan jurnal sebelumnya, yaitu ahli materi, ahli emodul dan uji coba kelompok kecil dijadikan penentuan apakah e-modul yang dibuat layak digunakan dalam pembelajaran (Herawati and Muhtadi, 2018), (Putra, Wirawan and Pradnyana, 2017), (Yuliawati, Aribowo and Hamid, 2020), (Aw, Rosidah and Kumoro, 2015)

E-Modul Humas atau Dulas mempunyai beberapa menu dan fitur didalamnya dan bisa membantu peserta didik dalam meningkatkan kemandirian dan hasil belajar peserta didik. Produk e-modul yang dikembangkan efektif dan dapat meningkatkan pemahaman belajar peserta didik (Herawati and Muhtadi, 2018) dan (Mertayasa, Agustini and Santyasa, 2018).

Untuk uji hasil belajar kelas kontrol dan kelas eksperimen disajikan dalam table 2 berikut ini: 
Jurnal Ekonomi, Bisnis dan Pendidikan, 1(6), 2021, 538-545

Tabel 2. Data hasil belajar

\begin{tabular}{llll}
\hline & & Kognitif & Psikomotorik \\
\hline Hasil Belajar & Kelas Kontrol & 73 & 76 \\
& Kelas Eksperimen & 92 & 86 \\
\hline
\end{tabular}

Table used by permission (CKarimah, Siti Akhlaqul, 2021. Data hasil belajar belajar

Tabel 2 menunjukkan bahwa hasil belajar peserta didik pada kelas eksperimen menunjukkan hasil rata-rata sebesar 89 dimana peserta didik memiliki nilai di atas KKM. Untuk kelas kontrol mendapatkan hasil rata-rata sebesar 74. Hal ini menunjukkan bahwa hasil belajar peserta didik kelas eksperimen mendapatkan hasil belajar yang lebih tinggi daripada kelas kontrol. Sejalan dengan penelitian sebelumnya yaitu e-modul dapat membantu peserta didik dalam belajar mandiri dan membantu peserta didik untuk memahami materi (Pramana, Jampel and Pudjawan, 2020), (Avisah and Bachri, 2020) dan (Asda, 2021)

Sedangkan untuk mengukur hasil kemandirian belajar peserta didik antara kelas kontrol dan kelas eksperimen menggunakan persentase. Yaitu sebagai berikut:

Tabel 3. Data kemandirian belajar

\begin{tabular}{lll}
\hline Kemandirian Belajar & Kelas Kontrol & 71 \\
\hline & Kelas Eksperimen & 97 \\
\hline
\end{tabular}

Table used by permission (CKarimah, Siti Akhlaqul, 2021. Data hasil kemandirian belajar

Tabel 3 menunjukkan bahwa hasil kemandirian belajar kelas kontrol memperoleh hasil 71 dan kelas eksperimen sebesar 97 dapat dikatakan bahwa kemandirian belajar peserta didik kelas eksperimen lebih tinggi daripada kelas kontrol. Sehingga E-Modul Humas yang dikembangkan dapat meningkatkan kemandirian belajar peserta didik (Asda, 2021)

\section{Simpulan}

Penelitian dan pengembangan ini menghasilkan E-Modul berbasis android menggunakan aplikasi Kvisoft Flipbook Maker untuk meningkatkan hasil belajar dan kemandirian peserta didik pada mata pelajaran Otomatisasi Tata Kelola Humas dan Keprotokolan kelas XI OTKP di SMK Terpadu Al-Ishlahiyah Singosari. E-Modul ini bisa di download melalui http://bit.ly/E-ModulHumas

E-Modul pada penelitian dan pengembangan ini dinyatakan "sangat valid" dan layak digunakan dalam pembelajaran humas menurut ahli media, ahli materi dan uji kelompok kecil. Selain itu, E-Modul telah terbukti efektif dan juga dapat meningkatkan hasil belajar dan kemandirian peserta didik pada uji coba kelompok besar berdasarkan hasil persentase. EModul ini juga bisa digunakan untuk pembelajaran dimanapun dan kapanpun secara mandiri tanpa harus tatap muka di sekolah, sehingga E-Modul ini berguna ketika pembelajaran tidak bisa tatap muka secara langsung dengan guru seperti saat adanya pandemic Covid-19.

E-Modul Humas hanya berfokus pada beberapa kompetensi dasar dan kompetensi inti dan terbatas pada sistem android, sehingga diharapkan untuk peneliti selanjutnya dapat mengembangkan E-Modul pada sistem operasi lainnya seperti IOS. 


\section{Ucapan Terima Kasih}

Penulis mengucapkan terimakasih kepada Universitas Negeri Malang dan SMK Terpadu Al-Ishlahiyah Singosari yang telah memfasilitasi dan memberi izin kepada peneliti untuk melakukan kegiatan penelitian dan pengembangan ini.

\section{Daftar Rujukan}

Asda, V. D. (2021) 'EDUKATIF : Efektivitas E-modul Berbasis Guided Inquiry Learning Terintegrasi Virlabs dan Multirepresentasi pada Materi Larutan Elektrolit dan Non Elektrolit terhadap Hasil Belajar Siswa', JURNAL ILMU PENDIDIKAN 3(3), pp. 710-716.

Avisah, M. N. and Bachri, B. S. (2020) 'Pengembangan E-Modul Berbasis Aplikasi Smartphone Materi Pokok Narkoba Dan Psikotropika Mata Pelajaran Penjaskes Untuk Meningkatkan Hasil Belajar Siswa Di Sma Muhammadiyah 7 Surabaya', Jurnal Mahasiswa Teknologi Pendidikan 10, pp. 1-8.

Aw, S., Rosidah, R., \& Kumoro, J. (2015). Pemetaan Kompetensi, Tugas, dan Pekerjaan Sekretaris di Dunia Kerja. Efisiensi: Kajian Ilmu Administrasi, 13(1).

Badrudin, A. R., Ginanjar, M. H. and Wartono, W. (2020) 'the Effectiveness of Online Based Learning During the Covid-19 Pandemic At Private School in Bogor', Edukasi Islami: Jurnal Pendidikan Islam, 9(02), p. 480. doi: 10.30868/ei.v9i02.909.

Damarsasi, D. G., \& Saptorini, S. (2018) 'Pengembangan E-Modul Berbasis Flip Book Maker Materi', Jurnal Pendidikan Ilmu Sosial, 27, pp. 1-10.

Divayana, D. G. H. et al. (2019) 'The Design of Digital Book Content for Assessment and Evaluation Courses by Adopting Superitem Concept Based on Kvisoft Flipbook Maker in era of Industry 4.0', Journal of Physics: Conference Series, 1165(1), pp. 0-6. doi: 10.1088/1742-6596/1165/1/012020.

Dwiantoro, A. Y. and Kusumandari, R. B. (2016) 'Meningkatkan Hasil Belajar Berbasis E-learning Elgg pada Model Project Based Learning', Indonesian Journal of Curriculum and Educational Technology Studies, 4(2), pp. 49-57. doi: 10.15294/ijcets.v4i2.14306.

Fonda, A. and Sumargiyani, S. (2018) 'the Developing Math Electronic Module With Scientific Approach Using Kvisoft Flipbook Maker Pro for Xi Grade of Senior High School Students', Infinity Journal, 7(2), p. 109. doi: 10.22460/infinity.v7i2.p109-122.

Fredy, F., Prihandoko, L. A. and Anggawirya, A. M. (2020) 'The Effect of Learning Experience on the Information Literacy of Students in the Ri-Png Border During Covid-19 Period', International Journal of Multicultural and Multireligious Understanding, 7(10), p. 171. doi: 10.18415/ijmmu.v7i10.2067.

Herawati, N. S. and Muhtadi, A. (2018) 'Pengembangan modul elektronik (e-modul) interaktif pada mata pelajaran Kimia kelas XI SMA', Jurnal Inovasi Teknologi Pendidikan, 5(2), pp. 180-191. doi: 10.21831/jitp.v5i2.15424.

Lestari, S. (2018) 'Peran Teknologi dalam Pendidikan di Era Globalisasi', Edureligia; Jurnal Pendidikan Agama Islam, 2(2), pp. 94-100. doi: 10.33650/edureligia.v2i2.459.

Linda, R. et al. (2018) 'Interactive E-Module Development through Chemistry Magazine on Kvisoft Flipbook Maker Application for Chemistry Learning in Second Semester at Second Grade Senior High School', Journal of Science Learning, 2(1), p. 21. doi: 10.17509/jsl.v2i1.12933.

Mertayasa, I. N. E., Agustini, K. and Santyasa, I. W. (2018) 'Efektivitas E-Modul Berorientasi Modalitas Gaya Belajar Pada Mata Pelajaran Komunikasi Data Kelas XI TKJ di SMK Negeri 3 Singaraja', Seminar Nasional Pendidikan Teknik Informatika (SENAPATI), 9(September), pp. 81-84.

Mishra, L., Gupta, T. and Shree, A. (2020) 'Online teaching-learning in higher education during lockdown period of COVID-19 pandemic', International Journal of Educational Research Open, 1(August), p. 100012. doi: 10.1016/j.ijedro.2020.100012.

Pramana, M. W. A., Jampel, I. N. and Pudjawan, K. (2020) 'Meningkatkan Hasil Belajar Biologi Melalui E-Modul Berbasis Problem Based Learning', Jurnal Edutech Undiksha, 8(2), p. 17. doi: 10.23887/jeu.v8i2.28921.

Putra, K. W. B., Wirawan, I. M. A. and Pradnyana, G. A. (2017) 'Pengembangan E-Modul Berbasis Model Pembelajaran Discovery Learning Pada Mata Pelajaran "Sistem Komputer" Untuk Siswa Kelas X Multimedia Smk Negeri 3 Singaraja', Jurnal Pendidikan Teknologi dan Kejuruan, 14(1), pp. 40-49. doi: 10.23887/jptk.v14i1.9880. 
Jurnal Ekonomi, Bisnis dan Pendidikan, 1(6), 2021, 538-545

Putri, R. A., Uchtiawati, S. and Fauziyah, N. (2020) 'Pengembangan Media Pembelajaran Interaktif Flip Book Menggunakan Kvisoft Flip Book Maker Berbasis Seni Budaya Lokal', DIDAKTIKA : Jurnal Pemikiran Pendidikan, 26(2), p. 1. doi: 10.30587/didaktika.v26i2.1468.

Ramdhani, M. A. and Muhammadiyah, H. (2015) The Criteria of Learning Media Selection for Character Education in Higher Education', Proceeding International Conference of Islamic Education: Reforms, Prospects and Challenges Faculty of Tarbiyah and Teaching Training The Criteria of Learning Media Selection for Character Education in Higher Education, pp. 174-182.

Sari, P. R., Tusyantari, N. B. and Suswandari, M. (2021) 'DAMPAK PEMBELAJARAN DARING BAGI SISWA SEKOLAH DASAR SELAMA SELAMA COVID-19 Universitas Veteran Bangun Nusantara, Sukoharjo', Prima Magistra: Jurnal Ilmiah Kependidikan, 2(1), pp. 9-15.

Sugiyono (2016) Metode Penelitian Kuantitatif, Kualitatif, dan R\&D. Cetakan Ke. Bandung: Alfabetha cv.

Wibowo, E. and Pratiwi, D. D. (2018) 'Pengembangan Bahan Ajar Menggunakan Aplikasi Kvisoft Flipbook Maker Materi Himpunan', Desimal: Jurnal Matematika, 1(2), p. 147. doi: 10.24042/djm.v1i2.2279.

Yuliawati, L., Aribowo, D. and Hamid, M. A. (2020) ‘Analisis Kebutuhan Pengembangan Media Pembelajaran EModul Berbasis Adobe Flash pada Mata Pelajaran Pekerjaan Dasar Elektromekanik', Jupiter (Jurnal Pendidikan Teknik Elektro), 5(1), pp. 35-42. 